Review article

\title{
Impact of plant invasion on physical, chemical and biological aspects of ecosystems: A review
}

\author{
Parvaiz Ahmad Lone, Javid Ahmad Dar, Kothandaraman Subashree, Debojyoti Raha, \\ Praveen Kumar Pandey, Tapas Ray, Pramod Kumar Khare \\ and Mohammed Latif Khan*
}

Biodiversity Conservation Division, Department of Botany, Dr. Harisingh Gour Central University Sagar, Madhya Pradesh-470003, India

*Corresponding Author: khanml@yahoo.com, khanml61@gmail.com

[Accepted: 26 December 2019]

\begin{abstract}
Biological invasion is considered as one of the major threats to native ecosystems. Here, we review the impacts of invasive plants on the physical, chemical and biological aspects of ecosystem functioning. Introduction of invasive plants impact ecosystems profoundly in a multitude of ways by modifying the physical (soil temperature, soil moisture, etc.), chemical (elemental composition, litter dynamics, nutrient cycles, allelopathy, etc.) and biological components (plant community structure, soil microbial biota and fauna). Most studies have shown a negative feedback of biological invasion on the physical, chemical and biological aspects of the ecosystems. Very often, a positive feedback has been generated between the physico-chemical and biological aspects that favour invasion success. Hence, the in-depth and long-term monitoring is needed to focus on the impact of invasive plants on the species diversity, soil biogeochemistry for better understanding of plant invasion processes in ecosystems, so that proper management strategies could be developed for combating the negative impacts of plant invasion.

Keywords: Exotic plants - Native ecosystems - Community structure - Biogeochemistry - Litter dynamics - Micro biota.
\end{abstract}

[Cite as: Lone PA, Dar JA, Subashree K, Raha D, Pandey PK, Ray T, Khare PK \& Khan ML (2019) Impact of plant invasion on physical, chemical and biological aspects of ecosystems: A review. Tropical Plant Research 6(3): 528-544]

\section{INTRODUCTION}

Biological invasion is a global problem that threatens natural ecosystems. It is the second-largest threat (after habitat destruction) to biodiversity (Drake et al. 2003, Wekhanya 2016) and is one of the major drivers of global change (Sardans et al. 2017). By definition, invasive species refers to those organisms that have moved from their native habitat to a new location, where they cause significant harm to the environment, economic systems and/or human health (Richardson et al. 2000, Tiwari 2005, Beck et al. 2008). In other words, invasive alien species are those species whose ranges have been altered either unintentionally (such as accidental introductions) or intentionally (such as purposeful introductions) by humans. This results in self-replacing populations over several life cycles and thus spread over large areas in the new habitat (Pyšek \& Richardson 2010, Richardson \& Rejmánek 2011, Abrahams et al. 2019). A successful biological invasion is one in which the alien species is capable of overcoming abiotic and biotic barriers and establishing self-sustaining populations (called naturalization) for a considerable distance away from the original place of introduction along the introduction-naturalization-invasion continuum (Richardson et al. 2000, Richardson \& Pyšek 2012, Gioria \& Osborne 2014). They occur in practically all kinds of terrestrial ecosystems (Vitousek 1994) and comprise $20 \%$ or more of the continental flora and 50\% or more of the island flora (Seabloom et al. 2006, Sardans et al. 2017). Among the different kinds of terrestrial ecosystems, montane ecosystems are considered to be at the lower risk of plant invasions due to the various ecological filters faced by the mountains as they move along high altitudes (Pauchard et al. 2009, Alexander et al. 2011, McDougall et al. 2011, Pathak et al. 2019). 
Invasive species typically are more tolerant than the native species to a wide range of environmental conditions and possess unique biological traits that offer them various competitive advantages (Sundarapandian et al. 2015, Sundarapandian \& Subashree 2017). Their widespread establishment could be attributed to their performance-related traits such as physiology, growth rates, shoot allocation, leaf-area allocation, size and fitness, etc. (Liao et al. 2008, van Kleunen et al. 2010, Stefanowicz et al. 2018). In addition, invasion success is also favoured by various other factors explained by hypotheses such as 'enemy release', 'empty niche', 'resource availability', 'novel weapons', 'disturbance hypothesis', etc. (Dar et al. 2019).

As per the International Union for Conservation of Nature (IUCN 2004), the impacts caused by the invasion of exotic species are usually immense, insidious and irreversible (Wekhanya 2016). They may colonize and dominate an urban area or a region of wilderness; particular land-use habitats or protected areas (Wekhanya 2016). The impacts caused by them are often categorized as follows: economic, social and environmental. Economic impacts are those consequences in which humans face direct monetary losses. Social impacts are those in which the human health or safety or other aspects of social culture are affected. Environmental impacts are those in which the ecosystem processes are affected leading to the loss of biodiversity and ecological functionality (Charles \& Dukes 2008, Wekhanya 2016). The rapid expansion of the invasive plant species with/without human influence has resulted in drastic modifications of natural ecosystems, threatening various ecosystem functions and services (Gordon 1998, Uddin \& Robbinson 2017). The invasion of exotic plant species could change entire ecosystems by altering physical, chemical and biological properties of the habitat, communities and ecosystems, by altering fire regimes, hydrology, nutrient cycling and other ecological processes (Pathak et al. 2019). The introduction of a new species in a new area exerts a great effect on the structure and/or ecosystem functioning. Such effects/impacts may be manifested at the level of populations or communities in the early stages of invasion and at an ecosystem-level at a later stage. While some impacts may be rapid and dramatic, others may be expressed slowly (Brooks et al. 2004, Pyšek \& Richardson 2010). Invasive species can induce changes in the ecosystem cycles such as water, carbon, nitrogen, etc. and affect soil nutrient dynamics, besides altering the biogeochemistry, geomorphology, hydrology and disturbance levels in ecosystems (Gordon 1998, Ehrenfeld 2003, Yadav et al. 2016, Dutta 2018). Simultaneous invasion by different invasive plant species could drastically alter the three-dimensional structure of forests (Asner et al. 2008, Kumari \& Choudhary 2016, Dutta 2018). Invasive plant species were also reported to form monospecific strands by outcompeting the native plant species, bringing about a great loss in plant diversity (Gaertner $\mathrm{et}$ al. 2009, Powell et al. 2011). The various threats posed by plant invasion to ecosystems could be summarized as: habitat loss, biodiversity decline, changes in litter quality, quantity and decomposition rates, soil physicochemical properties, soil biota, etc. (Theoharides \& Dukes 2007, Vilà et al. 2011, Dassonville et al. 2011, Sanon et al. 2012, Wang et al. 2015, Kumari \& Choudhary 2016). It is important to note that invasive plants exhibit different degrees of invasion in the affected areas (Theoharides \& Dukes 2007, Si et al. 2013) and the impacts may vary across local conditions, different seasons, soil type and the nature of the native community (Ehrenfeld 2003, Bjerknes et al. 2007, Dutta 2018).

Successful establishment of an invasive species could exacerbate the impacts of invasiveness by a phenomenon called 'invasional meltdown', which is caused by the co-facilitation of multiple invasive species, which might result in a 'stable degraded state' as in a grassland agro-ecosystem (Kulmatiski 2006, Best \& Arcese 2009, Jordan et al. 2011, Dar et al. 2019). As the globalization proceeds at a rapid pace, the number of alien species getting introduced into new areas continues to rise (van Kleunen et al. 2015, Helsen et al. 2018). The spread of invasive plant species has been reported to increase with trade, travel and technology and they have now colonized even forests, which were once considered to be low-risk areas (Meyerson \& Mooney 2007). Biological invasions have increased worldwide as invasive species could act as both 'drivers', by outcompeting and dominating the native species with their unique eco-physiological traits and abilities and 'passengers', by dominating a region as a consequence of anthropogenic actions such as environmental degradation, habitat fragmentation, global climate change, etc. (Powell et al. 2011, Dar et al. 2019). Assessment of the impacts of invasion is a major task in invasion science (Bartz \& Kowarik 2019) and the various ecological and economic losses caused by biological invasions have propelled various authorities to frame several policies and take management and restoration operations. As the plant-soil feedback interactions are induced by invasiveness via physico-chemical and biological mechanisms, it becomes important to understand the impacts of invasion on physical, chemical and biological aspects of ecosystems. This review aims to understand the various impacts of plant invasion on physical, chemical and biological aspects of ecosystems from various literary sources. The method of literature selection was done using the search terms "invasive plants", "biological invasion of plants", 
"native versus invaded ecosystems", "impact of plant invasion on physical aspects of ecosystems", "impact of plant invasion on chemical aspectsof ecosystems" and "impact of plant invasion on biological aspectsof ecosystems" in different search engines such as Google Scholar, Scopus and Web of Science.

\section{IMPACTS OF INVASION ON PHYSICAL ASPECTS}

Plant invasions alter the physical properties of the ecosystem in many ways, especially that of soil. Invasive species also alter the patterns of energy flow in trophic level interactions, food chains and food webs (Wekhanya 2016). The invasive species are well-known to modify the physical habitat as well by intensifying the disturbance regimes such as flooding, soil erosion and forest fires. Invasion by Lantana camara L. is known to alter fuel loads and a positive feedback exists with forest fires, constituting the fire-lantana cycle (Hiremath \& Sundaram 2005). Forest fire cycles could be influenced in different ways as for example when grasses invade shrublands, fire frequency and intensity are enhanced, whereas when trees invade grasslands, fire suppression occurs (Wekhanya 2016). Plant invasion can have a drastic effect on the physical environment by altering the rates of both carbon dioxide emission and sequestration and/or by the emission of volatile organic compounds as well as biologically important gases (Dukes \& Mooney 2004, Charles \& Dukes 2008).

Several invasive plant species are known to modify soil properties, which would favour their own development and propagation (van Breemen \& Finzi 1998). Many studies have reported that native species thrive well in native soil than the invaded soil, which indicates that the soil properties are altered when an invasive species is introduced in a new habitat (Ehrenfeld 2003, Sharma \& Raghubanshi 2011, Simba et al. 2013). Invasive species alter the physical habitat as well as soil properties such as surface soil temperatures, hydrological processes, etc. By influencing the abiotic and the biotic properties of the soil, invasive plants alter the soil's ability to support the same individuals or other individuals of the same invader species or other plant species and such interactions are known as 'plant-soil feedbacks', which play a crucial role in invasiveness (Ehrenfeld et al. 2005, Kulmatiski \& Kardol 2008, van der Putten et al. 2013). Invasive plant species can also make the soil less suitable for other species to grow by secreting salts increasing the soil salinity [e.g. Tamarix ramosissima Ledeb. (Zavaleta 2000) and Mesembryanthemum crystallinum L. (Vivrette \& Muller 1977) or by acidifying the soil (Callaway \& Ridenour 2004, Charles \& Dukes 2008, Wekhanya 2016].

As invasion takes over in a new habitat, the community structure of the ecosystem gets altered, which in turn changes the surface soil properties such as soil water and nutrient absorption capacities, heat capacity, soil temperature, etc., which would in turn affect root and shoot development of seedlings and saplings (Oades 1984, Hamblin 1986, Smith et al. 1987, Singh \& Sainju 1998, Gibbons et al. 2017, Stefanowicz et al. 2018, Caspi et al. 2019). Alteration in plant community structure also causes significant changes in soil properties such as water-holding potential and soil porosity. Changes in root characteristics are known to affect the soil pore size, pore distribution and pore continuity, which would in turn influence the hydraulic conductivity of the soil (Hamblin 1986, Radcliffe \& Rasmussen 2002).

Invasive plant species alter the hydrological cycles in the invaded environment via changing the rates and timings of evapotranspiration, runoff as well as water table levels. Such impacts vary with the variation in the invaders' traits such as rooting depth, leaf area index, transpiration rate, tissue biomass and phenology (Levine et al. 2003). Alteration in the water cycle would have profound changes in water supply and regulation, which would in turn affect humans (Levine et al. 2003, Charles \& Dukes 2008). Soil moisture, which is an important soil pool is also affected by the degree of plant invasion and changes in soil moisture due to plant invasion often results in changes in the microbial flora of the rhizosphere in a manner that promotes further invasiveness (Si et al. 2013). Soil moisture is a property that is influenced by rooting depth and the season of active uptake (such as summer) and as invasive plants have a deeper rooting depth and are active during different times of the year, soil moisture is affected due to the drawing up of large volumes of soil water (Enloe et al. 2004, Potts et al. 2008, Ehrenfeld 2010). The rapid growth and long persistence time of invasive plants, which leads to fast evapotranspiration rates, are also important causes for the decrease in soil moisture (Wolf et al. 2004, Wang et al. 2015). Apart from the rooting depth, the higher evapotranspiration rates are also caused due to larger plant sizes and greater leaf area than the native plant species. A well-known example is the case of Tamarix which is known for its ability to alter the water budget and water dynamics of the whole ecosystem due to its large leaf area (Sala et al. 1996, Ehrenfeld 2003). Thus, invasive alien plant species alter the physical environment of the invaded ecosystem via various mechanisms.

\section{IMPACTS OF INVASION ON CHEMICAL ASPECTS}

Plant invasion has been known to alter the chemical properties of the ecosystem causing considerable 
damage to the native biota and thereby ecosystem functions. Invasive plant species affect ecosystems via both direct and indirect effects on soil chemistry (Wekhanya 2016). The root and leaf exudates of the invasive plants affects soil structure, which could mobilize and chelate nutrients and microbial activities (Batten et al. 2006, Wekhanya 2016). The impacts of plant invasion on soil's chemical attributes is due to the modification of chemical inputs and patterns of cycling of carbon, nitrogen and other elements, soil organic matter, soil aggregation, soil pH and release of allelopathic substances (Saggar et al. 1999, Kourtev et al. 2002, Ehrenfeld 2003, Hawkes et al. 2005, Thorpe et al. 2009, Jordan et al. 2011). Invasive plants usually drastically change important soil characteristics such as carbon content, nitrogen content, $\mathrm{pH}$, nitrification rates, mineralization rates and concentrations of important elements such as calcium, magnesium and potassium (Simba et al. 2013). The success of invasive plants is often linked with alterations in the soil elemental composition and stoichiometry (Sardans et al. 2017).

One of the prominent impacts of plant invasion on the chemical properties of the ecosystem is the alteration in litter and nutrient dynamics of the ecosystem. Invasive plant species affect the various components of the carbon, nitrogen and nutrient cycles, inclusive of aboveground and belowground carbon compounds, net primary productivity, rates of litterfall, quality and quantity of litter as well as rates of nutrient and carbon mineralization (Hector et al. 1999, Chapin et al. 2000, Ehrenfeld 2003). The changes in the physical properties of the soil also drive changes in the nutrient dynamics (Boettcher \& Kalisz 1990, Kelly et al. 1998, Ehrenfeld 2001, Ehrenfeld 2003). Nutrient availability to primary producers is an important ecosystem service which is greatly altered when invasion occurs and the plant community structure is altered (Ehrenfeld 2003, Mack \& D'Antonio 2003, Dukes \& Mooney 2004). The nutrient cycles are influenced by invasive plants through three principal ways: alteration of soil microbial networks, changes in litter disintegration rates and changes in the soil's physico-chemical properties. The primary productivity is key ecosystem functions which could be altered if the ecosystem is invaded by invasive species that utilizes resources more efficiently and cause the elimination of a key native species (Dukes \& Mooney 2004). As primary productivity is altered, all other subsequent ecosystem services are also affected. Invasive species exhibit rapid rates of growth have high specific leaf area and accumulate more biomass than the native species (Daehler 2003). The large amounts of biomass accumulated by the invasive plant species differs considerably from that of native vegetation biomass in terms of chemical quality such as elemental composition, lignin content, carbon : nitrogen ratio, lignin : nitrogen ratio and secondary metabolite concentrations (Dassonville et al. 2007, Tharayil et al. 2013, Stefanowicz et al. 2018).

Litterfall and litter decomposition are important ecosystem processes that determine the carbon and nutrient cycles (Couteaux et al. 1995, Chen et al. 2011; Rai et al. 2016). Carbon fixed during photosynthesis is returned to the environment via litter decomposition, which is in turn used for plant development (Sayer 2006, Hobbie 2015). Large amounts of senescent plant biomass reach the soil via litterfall and if the litter quality and the litter decomposition rates are low, litter fragments may form a thick layer, in particular, if the invasive plant species produce less nutrient-rich or more recalcitrant litter than the native vegetation (Ehrenfeld 2003). In some instances, the litter of some invasive plant species exhibits only moderate rates of decomposition due to the presence of secondary metabolites (Boon \& Johnstone 1997). Plant invasion drives changes in topsoil chemical composition by uplifting nutrients from deep soil horizons (Dassonville et al. 2007, Stefanowicz et al. 2018). In other cases, invasive species contain low concentrations of lignin and polyphenolics and high concentrations of nutrients. The litter decomposition rates of these invasive plant litters are very high and nutrients are quickly discharged into the environment expediting nutrient cycles (Allison \& Vitousek 2004, Rothstein et al. 2004). In such cases, in spite of copious amounts of litterfall, due to rapid decomposition, there is less standing crop litter (Cameron \& Spencer 1989). A global meta-analysis by Liao et al. (2008) across 94 studies revealed that litter decomposition rates raised upto $117 \%$ in the invaded ecosystems, although the rates of litter decomposition might vary across different spatial scales (Wekhanya 2016). The invasive plants could affect leaf litter decomposition directly by changing the quality of leaf litter or indirectly by creating unique conditions in the surrounding environment. The concentration of nitrogen in the litter is an important indicator of litter quality, which also affects the rate of litter decomposition. High-quality litters contain high nitrogen concentration, while low-quality litters contain low nitrogen concentration (Rai et al. 2016). Moreover, the leaf litter of invasive plants contains lesser lignin and lower lignin: nitrogen ratios than the native plant species, which accounts for its higher decomposition rates. Leaf litter decomposition and the accompanied release of carbon dioxide and nutrients together with the formation of soil organic matter are the key fundamental processes that influence ecosystem nutrient cycles, carbon flux and humus formation (Wang et al. 2011, Zhang et al. 2014, Wang et al. 2015). 
Changes in litter composition and litter decomposition can exhibit marked effects on nutrient cycling. Nutrient cycling is also altered by plant invasion, if colonized by plants that fix nitrogen or if they leach chemicals that inhibit nitrogen fixation or if they release compounds that would affect the ability of nutrient retention (Dukes \& Mooney 2004). Nutrient cycling alterations by invasive species often vary in both magnitude and direction depending on the type of invasive species and the invaded habitat. The alteration of nutrient cycling also affects primary productivity and soil fertility (Ehrenfeld 2003). The soils of the ecosystems that were heavily infested with Lantana camara L. populations had high concentrations of organic carbon and nitrogen (Sharma \& Raghubanshi 2011). The changes caused in nutrient cycling often make the habitat less suitable for the growth of other species (Wekhanya 2016). One often perceived change in nutrient cycling is that the total nitrogen found mostly in organic reservoirs is transformed into various states by means of microbial immobilization and mineralization (Nannipieri et al. 2003). The nitrogen cycle plays an important role in successful plant invasions (Theoharides \& Dukes 2007, Jones \& Chapman 2011, Wang et al. 2015). High levels of nitrogen lead to an increase in the biomass of invasive plants and a decrease in the biomass of native plants. This is primarily because invaders are more efficient in resource utilization and have lesser nutrient requirements than the native plant species (Rickey \& Anderson 2004, Gurevitch et al. 2008, Wang et al. 2015).

Invasive plants cause changes to nutrient cycles either dramatically or gradually. The nutrient cycles get altered dramatically when invasive plant species introduce new traits in the ecosystem, which makes resources available from new/unused sources. On the other hand, nutrient cycles are gradually changed when some functional traits possessed by the invasive species induces high rates of nutrient uptake or turnover (Mack et al. 2001, Wang et al. 2015). Plants principally use two types of nitrogen directly - nitrate nitrogen and ammonium nitrogen. Invasive plants create a microenvironment with increased nitrogen availability that would facilitate further invasion (Hawkes et al. 2005, Liao et al. 2008, Wang et al. 2015).

Soil $\mathrm{pH}$ refers to the concentration of hydrogen ions (or protons) in the soil and plant invasion is known to significantly increase the values of soil $\mathrm{pH}$. This could be because invasive plants have high rates of nitrate uptake leading to a decrease in soil nitrite concentration. The decrease in soil nitrite concentration causes a rise in soil pH (Ehrenfeld et al. 2001, Fan et al. 2010, Si et al. 2013). However, the nitrogen acquired by invasive plants can influence soil $\mathrm{pH}$ in either way - high ammonium absorption leads to acidification, while high nitrate absorption could cause alkalinization (Kourtev et al. 1998, Wang et al. 2015). The alteration of soil pH is also dependent on the degree of invasion as in some cases, low degrees of invasion increased soil $\mathrm{pH}$, whereas high degrees of invasion caused no change in soil pH (Si et al. 2013, Wang et al. 2015). High soil pH is known to increase the rate of litter decomposition and it, therefore, plays a critical role in the regulation of nutrient cycles (Wekhanya 2016).

Alongside the nitrogen cycle, the carbon cycle is also greatly influenced by plant invasion. By altering the plant community structure, invasion by exotic plants alters the aboveground and belowground biomass and thereby carbon stocks. Invasion by woody plants was found to cause about 1.5 fold increase in the soil organic carbon and soil total nitrogen content (Liao et al. 2006). The impacts are more pronounced on grassland ecosystems than most other terrestrial ecosystems as grasslands are very susceptible to plant invasion. According to Connin et al. (1997), the invasion and subsequent replacement of grasses in grasslands lead to alterations in leaf litter, root mass, soil nutrient availability, soil carbon sequestration and cycling. When the grasslands are invaded by shrubs, the soil organic carbon pool is affected due to the modification of the quality and quantity of carbon sources (Amundson 2001, Jackson et al. 2002). However, the impact of plant invasion on carbon cycling is also dependent on other environmental factors. For example, plant invasion was noted to increase the soil organic carbon pool in dry sites while a decrease in soil organic carbon pool was observed in wet sites. The loss of carbon from the soil was found to be greater than the carbon accrued in the phytomass of the wet sites (Jackson et al. 2002).

Invasion by exotic plant species greatly affects the biogeochemical pools and fluxes of both matter and energy, which therefore alters the fundamental functions of ecosystems (Ehrenfeld 2010). Soil respiration is a widely measured flux of carbon dioxide from the soil surface. It is a measure of the soil metabolic activity representing the carbon dioxide produced by soil organisms such as microbes, plant roots and fauna. Soil respiration is one of the major causes of carbon loss from the ecosystem (Schlesinger \& Andrews 2000). Hence, even a slight shift in soil respiration due to plant invasions could result in great changes in the atmospheric carbon dioxide concentration and the soil carbon pool. Although plant invasions could substantially alter soil respiration rates, researchers have obtained positive, negative and negligible effects. These differences could be attributed to the differences in factors determining soil respiration and different site conditions (Fang \& 
Moncrieff 2001, McCulley et al. 2004, Smith \& Johnson 2004, Metcalfe et al. 2011).

The impacts of plant invasion on nitrogen and carbon cycles are often well-studied, but the impacts on phosphorous cycle and cations are seldom documented (Ehrenfeld 2010). Invasion by alien plants and soil phosphorous are often correlated (Martin et al. 2009). In general, soil phosphorous is found to increase following plant invasions (Duda et al. 2003, Hughes \& Denslow 2005, Vanderhoeven et al. 2006), but some studies noted a decrease or a lack of change in soil phosphorous content (Collins \& Jose 2009, Martin et al. 2009 , Ehrenfeld 2010). When plant invasion causes a decrease in soil $\mathrm{pH}$, the solubility of phosphorous in soil is enhanced and high phosphorous availability often facilitates further invasion (Herr et al. 2007, Chen et al. 2009, Wang et al. 2015). The cation pools also show fluctuations (increase or decrease or in some cases, no change) in response to plant invasion, although these are largely dependent on field conditions (Ehrenfeld 2010).

A major reason for invasion success by means of chemical modification of the environment is allelopathy. Allelopathy could be defined as "any impact, direct or indirect, positive or negative (e.g., phytotoxicity, soil sickness) of one organism on the growth and development of another organism through the release of chemical compounds into the environment" (Rice 1984, Elakovich \& Wooten 1989; Cheng \& Cheng 2015). Allelochemicals are usually released from roots, shoots, leaves or flowers which negatively affect the neighboring native species (Rice 1974). Allelopathy is a mechanism as suggested by 'novel weapons', where the invasive plant species negatively impacts native plant species which do not have tolerance or resistance to allelochemicals (Callaway \& Ridenour 2004, Yadav et al. 2016). Allelopathy can affect the native plants directly by impacting germination and growth or indirectly by altering the environment which would in turn affect the native plant species (Cipollini et al. 2012). As allelopathy could alter the physiology of the species, it could alter the plant community structure (Rice 1992) which would in turn affect the litter and nutrient dynamics of the ecosystem. Allelopathy is a chemical means of interference competition where the basic nature of the substrates gets altered which affects the nutrient uptake of native plants and therefore the plant growth. The effects of allelochemicals are usually greater in the introduced range than the native range (Callaway et al. 2004, Inderjit et al. 2011, Gioria \& Osborne 2014). Some studies have however reported that the secretion and release of allelochemicals as a means of resource competition may eventually reduce the growth of the same plant species and enhance their palatability to herbivores in the long run (Rasher \& Hay 2014, Gioria \& Osborne 2014).

The plant invasion thus causes serious deleterious impacts to the ecosystem by drastically altering the chemical properties and the effects may remain for a long time even after the invasive plant has been removed known as 'soil-legacy effects' (Jordan et al. 2011). Moreover, when the chemical exudates are leached from plants by rain or soil erosion, the chemical properties of soil at distant places away from the site of introduction are also invariably affected.

\section{IMPACTS OF INVASION ON BIOLOGICAL ASPECTS}

Invasive plants affect not only the abiotic components of the ecosystem, but also the biotic components. Invasive species affect the biological components of the ecosystem in various ways. The invasive plant species affect the species richness, evenness and abundance of the native plant species reducing the local species diversity and thereby drastically changing the unique characteristics of the original biological community present in the habitat (Olden \& Poff 2003, Winter et al. 2009, Pyšek et al. 2012, Rastogi et al. 2015, Wekhanya 2016). Invasive plants have the ability to cause variations even at the level of genes of native populations by means of hybridization (Vilà et al. 2000, Pyšek et al. 2012). Invasive species may affect the species diversity and community structure by either exploitation competition (e.g. indirect interactions like resource-use) or by interference competition (e.g. direct interactions like allelopathy) or both (Callaway \& Ridenour 2004, Charles $\&$ Dukes 2008). The impacts of invasive species via different kinds of interactions such as parasitism, predation, mutualism, herbivory, etc. can markedly alter the abundance of species, sometimes those with key traits that are essential to ecosystem functioning (Chapin et al. 2000, Charles \& Dukes 2008). Invasive species also disrupt food chains, food webs by affecting energy flows and sometimes by eliminating keystone species (Dukes \& Mooney 2004, Charles \& Dukes 2008).

Not all the species that are introduced may thrive, although some may survive, become dominant and eventually replace the native species and become invasive. The native species diversity becomes dwindled or in some cases become locally extinct because they are unprepared to defend themselves from the invasiveness of the new species introduced. Invasive species alter the nutrient cycling and this may alter the microbial load as well as composition (van der Heijden et al. 2008). Overall, invasive plants pose various impacts on the native 
biodiversity which could be summarized as follows: decrease in the diversity, density and abundance of the species (Kandwal et al. 2009); replacing the economically and ecologically important fodder grasses, medicinal plants, etc. (Bughani \& Rajwar 2005); favouring the invasion of other alien species over the native endemic species (Dobhal et al. 2011); inhibiting the seed germination and growth of native flora (Bhardwaj et al. 2014); reducing the nutrient content of the soil by altering the soil physico-chemical properties (Bhatt et al. 1994) and homogenization of natural habitats (Dar \& Reshi 2015, Pathak et al. 2019).

Invasive species alter the biological properties of the ecosystem via different methods. Apart from influencing the abiotic components and affecting the ecosystem processes, they are known to drastically alter the diversity and composition of both aboveground and belowground flora (Levine et al. 2003, Gaertner et al. 2009, Gioria et al. 2014, Gioria \& Osborne 2014). Changes in the aboveground and belowground flora would also influence the nature of foliar herbivores as well as the natural enemies of these herbivores (Pineda et al. 2010, Soler et al. 2012, van der Putten et al. 2013). It would also in turn affect the diversity and composition of soil biota (van der Putten et al. 2013). The successful establishment of invasive species is mostly linked with better resource-use efficiency of the species that is attributed to its superior capacity to compete for various kinds of resources. Resource competition plays a major role in determining invasion success as it is involved in both naturalization and invasion phases (Beerling et al. 1994, Vilà \& Weiner 2004, Gioria \& Osborne 2014).

Water is a major resource for which the invasivespecies compete for in order to successfully establish themselves (Thebaud et al. 1996). Although native species are expected to succeed in the competition for water due to presumed adaptation strategies, invasive species prove to be better competitors in environments with water deficits (Nernberg \& Dale 1997, Mason et al. 2012, Gioria \& Osborne 2014). Another major resource the invasive species compete for is the light where the larger plant species obtain disproportionately large share of this resource, suppressing the smaller individuals (Keddy \& Shipley 1989, Freckleton \& Watkinson 2001). Invasive species usually have superior capacity to capture light energy due to larger sizes, higher specific leaf area, etc. than the native species and the subsequent shading caused hinders the native individuals (Hobbs \& Mooney 1986, Hutchinson \& Vankat 1997, Richardson et al. 2000, Kueffer et al. 2007, Iponga et al. 2008, Gioria \& Osborne 2014). The reduction of light penetration at the ground level due to the establishment of invasive species often suppresses the growth of herbs. Although physical space is not a consumable resource, it is nevertheless an important factor for competition as it determines the access to other resources such as water, light and nutrients (McConnaughay \& Bazzaz 1991, Gioria \& Osborne 2014). Phenology plays a crucial role in determining better utilization of resources. Early growth offers a competitive advantage to invasive species as it leads to early utilization of resources and avoid competition with the native species (Tiley et al. 1996, Wilsey et al. 2011, Wolkovich \& Cleland 2011, Gioria \& Osborne 2014). Invasive species experience not only interspecific competition with the native species, but also intraspecific competition with the neighbouring individuals (Weiner 1993, Suding \& Goldberg 1999). The dominant species play a crucial role in determining the community structure of forest and other terrestrial ecosystems (Grime 1998, Smith et al. 2004). Both the dominant native species and the dominant invasive species compete for the same resources and increase their biomass (Grime 1998). Bottollier-Curtet et al. (2013) compared the dominant native and dominant alien invasive species and observed that dominant invasive species produced significantly greater aboveground and belowground biomass (Gioria \& Osborne 2014).

The longer persistence of invasive species in a community than the native species could be owed to its phenotypic plasticity, which is the ability of a particular genotype to express a wide range of phenotypes in response to various environmental conditions. Phenotypic plasticity is often attributed to the enhancement of niche breadth (Bradshaw 1965, Richards et al. 2006). As invasive species possess high phenotypic plasticity in various morphological and eco-physiological traits, they out-compete most other species and successfully establish themselves (Gioria \& Osborne 2014). The reason that could be attributed for successful establishment of invasive species is that they possess the ability to undergo rapid evolutionary changes in accordance with the novel environmental conditions in which they are introduced and hence adapt themselves quickly (Bossdorf $e t$ al. 2005). Apart from the diverse and direct competitions that the invasive species face, they also face indirect competitions such as the competition for pollinators. Invasive species are often known to disrupt the native plant-pollinator relationships as re-visitation to native species is reduced in the presence of invasive species (Brown et al. 2002, Muñoz \& Cavieres 2008, Palladini \& Maron 2013, Gioria \& Osborne 2014).

Apart from influencing the native plant community structure and composition, invasive plants also cause changes in the soil microbial communities in such a way that it results in a positive feedback for the invasive plant species and a negative feedback for the native plant species (Callaway et al. 2004, Kulmatiski et al. 2008, 
Callaway et al. 2008, TeBeest et al. 2009, Sanon et al. 2012, Si et al. 2013). As the litter quality gets varied with the prevalence of invasive plant species, the microbial community which decomposes the litter also gets altered (Wang et al. 2015). Moreover, as both invasive and native species occur in the same community, litter mixing occurs wherein the litter of invasive species is mixed with that of native species. Litter mixing brings about changes in resource quality and structure which therefore leads to changes in the microbial community composition (Chen et al. 2013, Zhang et al. 2014, Wang et al. 2015). The bacteria are known to dominate in early succession which is gradually replaced by fungi in late succession (Jiang et al. 2009, Si et al. 2013). In many cases, fungi are known to dominate the low-quality litters as they have lower nutrient requirements than the bacteria (Wang et al. 2011, Wang et al. 2015). This is so because in general, fungi have a greater carbon: nitrogen ratio than bacteria, which therefore has lesser nutrient requirements. Given that the access to carbon is equal but nitrogen is limited, then the microbial community shifts towards fungal dominance. On the other hand, if there is no limitation of nitrogen, then the microbial community shifts towards bacterial dominance (Simba $e t$ al. 2013, Wekhanya 2016).

When the soil microbial community composition gets altered with invasive plants, their ecosystem functions also change from that of original microbial community, which would in turn impede with ecosystem processes (Ehrenfeld 2003). Invasive plants therefore interfere with the co-operation existing between the soil microbes/networks and the native plants which would in turn facilitate invasion success (Reinhart \& Callaway 2006, Dawson \& Schrama 2016, Ricciardi et al. 2017). The introduction of invasive plants in a healthy ecosystem often disturbs the mutualistic relationships between fungi and the native plants, especially mycorrhizal associations. Invasive plant species usually disrupt such mutualistic relationships either by modifying soil food webs or by altering the soil nutrient dynamics or by instigating pathogens (Ehrenfeld et al. 2005). Therefore, soil microbes are often considered to be one of the key factors that either encourage or suppress plant invasions (van der Putten et al. 2013, Inderjit \& Cahill 2015).

Soil microbial community plays a critical role in litter decomposition and nutrient cycling through the action of soil enzymes. The most important soil enzymes are $\beta$-glucosidases, proteases, ureases and phosphatases which are involved in carbon, nitrogen and phosphorous cycles (Sardans \& Penuelas 2005, Sardans et al. 2008). The action of soil enzymes is dependent on soil microbial networks (Allison \& Vitousek 2004). When invasive plants take over a new habitat, the soil networks are disrupted leading to the interference in the activity of these important enzymes that are responsible for soil fertility and soil maintenance (Aon \& Colaneri 2001, Flory \& Clay 2010).

Plant invasions not only affect the native plants and soil microbial community, but they also affect soil fauna. Plant invasion affects soil micro-fauna as well as invertebrates inhabiting both aboveground and belowground (Kourtev et al. 2003, Qin et al. 2019). Invertebrates play an important role in the decomposition of organic matter as they quicken the decomposition of litter and nutrient release, especially in tropical forests (Schadler \& Brandl 2005, Lavelle et al. 2006, Meyer et al. 2011). However, the decomposition activity of invertebrates largely depends on litter chemistry and also the decomposer network (Powers et al. 2009). The introduction of alien invasive species in an ecosystem is found to decrease the species richness and diversity of the native invertebrate fauna. However, the impacts of plant invasion on invertebrate fauna may vary depending on the invasive species involved as some plant invasions favour certain kinds of invertebrate fauna and eliminate other taxa (McGrath \& Binkley 2009, Qin et al. 2019).

Changes in plant community structure arising due to plant invasion have proven to be detrimental to arthropods because many arthropods require specific plants for food and reproduction (Litt et al. 2014). The novel plants introduced may not be recognized by native arthropods leading to reduction in the latter's abundance and diversity (Tallamy 2004). Moreover, changes in the stand structure caused due to plant invasions may restrict arthropod movement, distribution and therefore reproduction by modifying the environmental conditions such as light, temperature, moisture, etc. (Wolkovich et al. 2009, Talley et al. 2012, Litt et al. 2014). The alteration in soil physico-chemical properties such as soil $\mathrm{pH}$, soil salinity, soil nutrient availability, soil moisture, etc. due to plant invasions may affect the diversity and reproduction of belowground-dwelling arthropods (Gratton \& Denno 2005). The changes in arthropod composition and distribution would also inflict changes in the predator composition and distribution (Pearson 2009, Litt et al. 2014). Among the various functional groups affected by plant invasion, only the detritivores are likely to benefit due to the plentiful availability of food and favourable microclimatic conditions (Levin et al. 2006). As per Standish (2004), the rate of litter decomposition is higher in invaded areas than in non-invaded areas, which indicates the abundance of detritivores in invaded areas. Such an ecosystem-wide abundance and distribution of detritivores would lead to 
ecosystem-wide shifts in trophic dynamics - from feeding on live vegetation to feeding on detritus (Gratton \& Denno 2006, Levin et al. 2006, Litt et al. 2014). Thus, plant invasions greatly affect the biological aspects of ecosystems.

\section{CONCLUSION}

Thus, it becomes evident from the review that plant invasions are a global concern that impact the physical, chemical and biological aspects of the ecosystems. The impacts of the plant invasions may vary according to the spatio-temporal context as well as the idiosyncratic properties of the invasive species. Due to increased globalization, there is a great chance for both unintentional/intentional introductions of species into new environments. Moreover, invasive species are well-known to expand their ranges towards high latitudes and altitudes due to climate change and exacerbated by anthropogenic disturbances. Therefore, more stringent screening and monitoring methods have to be adopted to check undesirable introductions. Based on the available data repositories, the species related to the already known invasive species should be screened for traits of invasiveness. In the case of infested ecosystems, the functional trait-based approach, viz. early detection and rapid response, eradication, mitigation and restoration should be used to restore ecosystems. A better understanding on the impacts of biological invasion on biogeochemistry of forest ecosystems, long-term monitoring is needed for developing proper management strategies to combat plant invasions.

\section{ACKNOWLEDGMENTS}

The first author is thankful to UGC for its fellowship and Dr. Harisingh Gour Vishwavidyalaya for providing all the necessary facilities. Authors declare no conflict of interest. Finally, we thank the anonymous reviewers for their valuable comments that greatly improved this review. This study was supported by the Department of Biotechnology, Government of India (No. BT/ PR12899/NDB/39/506/2015 dt. 20/06/2017) and Science and Engineering Research Board (SERB), Department of Science and Technology, New Delhi for partial funding under National Post-Doctoral Fellowship Scheme (Ref. No.: PDF/2015/000447) to the second author.

\section{REFERENCES}

Abrahams B Sitas N \& Esler KJ (2019) Exploring the dynamics of research collaborations by mapping social networks in invasion science. Journal of environmental management 229: 27-37.

Alexander JM, Kueffer C, Daehler CC, Edwards PJ, Pauchard A, Seipel T \& Miren C (2011) Assembly of nonnative floras along elevational gradients explained by directional ecological filtering. Proceedings of the National Academy of Sciences 108(2): 656-661.

Allison SD \& Vitousek PM (2004) Rapid nutrient cycling in leaf litter from invasive plants in Hawaii. Oecologia 141(4): 612-619.

Amundson R (2001) The carbon budget in soils. Annual Review of Earth and Planetary Sciences 29(1): 535562.

Aon MA \& Colaneri AC (2001) Temporal and spatial evolution of enzymatic activities and physico-chemical properties in an agricultural soil. Applied Soil Ecology 18(3): 255-270.

Asner GP, Hughes RF, Vitousek PM, Knapp DE, Kennedy-Bowdoin T, Boardman J, Martin RE, Eastwood M \& Green RO (2008) Invasive plants transform the three-dimensional structure of rain forests. Proceedings of the National Academy of Sciences 105(11): 4519-4523.

Bartz R \& Kowarik I (2019) Assessing the environmental impacts of invasive alien plants: A review of assessment approaches. NeoBiota 43: 69.

Batten KM, Scow KM, Davies KF \& Harrison SP (2006) two invasive plants alter soil microbial community composition in serpentine grasslands. Biological Invasions 8(2): 217-230.

Beck KG, Zimmerman K, Schardt JD, Stone J, Lukens RR, Reichard S, Randall J, Cangelosi AA, Cooper D \& Thompson JP (2008) Invasive species defined in a policy context: Recommendations from the Federal Invasive Species Advisory Committee. Invasive Plant Science and Management 1(4): 414-421.

Beerling DJ, Bailey JP \& Conolly AP (1994) Fallopia japonica (Houtt.) ronsedecraene. Journal of Ecology 82(4): 959-979.

Best RJ \& Arcese P (2009) Exotic herbivores directly facilitate the exotic grasses they graze: mechanisms for an unexpected positive feedback between invaders. Oecologia 159(1): 139-150.

Bhardwaj S, Kapoor KS, Singh HP (2014) Studies on allelopathic effects of Ageratina adenophora sprengel (King and Robinson) on some weed plants growing in forest ecosystem. International Journal of Theoretical and Applied Science 6(2): 1.

www.tropicalplantresearch.com 
Bhatt YD, Rawat YS \& Singh SP (1994) Changes in ecosystem functioning after replacement of forest by Lantana shrubland in Kumaun Himalaya. Journal of Vegetation Science 5(1): 67-70.

Bjerknes AL, Totland $\varnothing$, Hegland SJ \& Nielsen A (2007) Do alien plant invasions really affect pollination success in native plant species? Biological conservation 138(1-2): 1-12.

Boettcher SE \& Kalisz PJ (1990) Single-tree influence on soil properties in the mountains of eastern Kentucky. Ecology 71(4): 1365-1372.

Boon PI \& Johnstone L (1997) Organic matter decay in coastal wetlands: an inhibitory role for essential oil from Melaleuca alternifolia leaves? Archivfür Hydrobiologie 138(4): 433-449.

Bossdorf O, Auge H, Lafuma L, Rogers WE, Siemann E \& Prati D (2005) Phenotypic and genetic differentiation between native and introduced plant populations. Oecologia 144(1): 1-11.

Bottollier-Curtet M, Planty-Tabacchi AM \& Tabacchi E (2013) Competition between young exotic invasive and native dominant plant species: implications for invasions within riparian areas. Journal of Vegetation Science 24(6): 1033-1042.

Bradshaw AD (1965) Evolutionary significance of phenotypic plasticity in plants. Advances in Genetics 13: $115-155$.

Brooks ML, D'antonio CM, Richardson DM, Grace JB, Keeley JE, DiTomaso JM, Hobbs RJ, Pellant M \& Pyke D (2004) Effects of invasive alien plants on fire regimes. BioScience 54(7): 677-688.

Brown BJ, Mitchell RJ \& Graham SA (2002) Competition for pollination between an invasive species (purple loosestrife) and a native congener. Ecology 83(8): 2328-2336.

Bughani I \& Rajwar GS (2005) Primary productivity and the impacts of the exotic weed Eupatorium glandulosum in Montane grassland of Garhwal Himalaya. Environmentalist 25(1): 31-38.

Callaway RM \& Ridenour WM (2004) Novel weapons: invasive success and the evolution of increased competitive ability. Frontiers in Ecology and the Environment 2(8): 436-443.

Callaway RM, Cipollini D, Barto K, Thelen GC, Hallett SG, Prati D, Stinson K \& Klironomos J (2008) Novel weapons: invasive plant suppresses fungal mutualists in America but not in its native Europe. Ecology 89(4): 1043-1055.

Callaway RM, Thelen GC, Rodriguez A \& Holben WE (2004) Soil biota and exotic plant invasion. Nature 427(6976): 731.

Cameron GN \& Spencer SR (1989) Rapid leaf decay and nutrient release in a Chinese tallow forest. Oecologia 80(2): 222-228.

Caspi T, Hartz LA, Villa AES, Loesberg JA, Robins CR \&Meyer III WM 2019 Impacts of invasive annuals on soil carbon and nitrogen storagein southern California depend on the identity of the invader. Ecology and Evolution 9: 4980-4993.

Chapin Iii FS, Zavaleta ES, Eviner VT, Naylor RL, Vitousek PM, Reynolds HL, Hooper DU, Lavorel S, Sala OE, Hobbie SE, Mack MC \& Diaz S (2000) Consequences of changing biodiversity. Nature 405(6783): 234.

Charles H \& Dukes JS (2008) Impacts of invasive species on ecosystem services. In: Biological invasions. Springer, Berlin, Heidelberg, pp. 217-237.

Chen BM, Peng SL \& Ni GY (2009) Effects of the invasive plant Mikaniamicrantha HBK on soil nitrogen availability through allelopathy in South China. Biological Invasions 11(6): 1291-1299.

Chen BM, Peng SL, D’Antonio CM, Li DJ \&Ren WT (2013) Non-additive effects on decomposition from mixing litter of the invasive Mikania micrantha HBK with native plants. PloS one 8(6): e66289.

Chen GS, Yang YS, Guo JF, Xie JS \& Yang ZJ (2011) Relationships between carbon allocation and partitioning of soil respiration across world mature forests. Plant Ecology 212(2): 195-206.

Cheng F \& Cheng Z (2015) Research Progress on the use of Plant Allelopathy in Agriculture and the Physiological and Ecological Mechanisms of Allelopathy. Frontiers in Plant Science 6: 1020

Cipollini K, Titus KYLE \& Wagner C (2012) Allelopathic effects of invasive species (Alliariapetiolata, Loniceramaackii, Ranunculus ficaria) in the Midwestern United States. Allelopathy Journal 29(1): 63-76.

Collins AR \& Jose S (2009) Imperata cylindrica, an exotic invasive grass, changes soil chemical properties of forest ecosystems in the southeastern United States. In: Invasive plants and forest ecosystems. CRC Press, Boca Raton, pp. 237-250.

Connin SL, Virginia RA \& Chamberlain CP (1997) Carbon isotopes reveal soil organic matter dynamics following arid land shrub expansion. Oecologia 110(3): 374-386.

Couteaux MM, Bottner P \& Berg B (1995) Litter decomposition, climate and liter quality. Trends in Ecology and Evolution 10(2): 63-66. 
Daehler CC (2003) Performance comparisons of co-occurring native and alien invasive plants: implications for conservation and restoration. Annual Review of Ecology, Evolution, and Systematics 34(1): 183-211.

Dar JA, Subashree K, Sundarapandian S, Saikia P, Kumar A, Khare PK, Dayanandan S \& Khan ML (2019) Invasive Species and Their Impact on Tropical Forests of Central India: A Review. In: Tropical Ecosystems: Structure, Functions and Challenges in the Face of Global Change. Springer, Singapore, pp. 69-109.

Dar PA \& Reshi ZA (2015) Do alien plant invasions cause biotic homogenization of terrestrial ecosystems in the Kashmir Valley, India. Tropical Ecology 56(1): 111-123.

Dassonville N, Guillaumaud N, Piola F, Meerts P \& Poly F (2011) Niche construction by the invasive Asian knotweeds (species complex Fallopia): impact on activity, abundance and community structure of denitrifiers and nitrifiers. Biological invasions 13(5): 1115-1133.

Dassonville N, Vanderhoeven S, Gruber W \& Meerts P (2007) Invasion by Fallopia japonica increases top soil mineral nutrient concentrations. Ecoscience 14(2): 230-240.

Dawson W \& Schrama M (2016) Identifying the role of soil microbes in plant invasions. Journal of Ecology 104(5): 1211-1218.

Dobhal PK, Kohli RK \& Batish DR (2011) Impact of Lantana camara L. invasion on riparian vegetation of Nayar region in Garhwal Himalayas (Uttarakhand, India). Journal of Ecology and the Natural Environment 3(1): 11-22.

Drake SJ, Weltzin JF \& Parr PD (2003) Assessment of non-native invasive plant species on the United States Department of Energy Oak Ridge National Environmental Research Park. Castanea 68: 15-30.

Duda JJ, Freeman DC, Emlen JM, Belnap J, Kitchen SG, Zak JC, Sobek E, Tracy M \& Montante J (2003) Differences in native soil ecology associated with invasion of the exotic annual chenopod, Halogeton glomeratus. Biology and Fertility of Soils 38(2): 72-77.

Dukes JS \& Mooney HA (2004) Disruption of ecosystem processes in western North America by invasive species. Revistachilena de Historia Natural 77(3): 411-437.

Dutta H (2018) Insights into the phenomenon of alien plant invasion and its synergistic interlinkage with three current ecological issues. Journal of Asia-Pacific Biodiversity 11(2): 188-198.

Ehrenfeld JG (2001) Plant-soil interactions. In: Levin S (ed) Encyclopedia of biodiversity. San Diego (CA): Academic Press, pp. 689-709.

Ehrenfeld JG (2003) Effects of exotic plant invasions on soil nutrient cycling processes. Ecosystems 6(6): 503523.

Ehrenfeld JG (2010) Ecosystem consequences of biological invasions. Annual Review of Ecology, Evolution, and Systematics 41: 59-80.

Ehrenfeld JG, Kourtev P \& Huang W (2001) Changes in soil functions following invasions of exotic understory plants in deciduous forests. Ecological applications 11(5): 1287-1300.

Ehrenfeld JG, Ravit B \& Elgersma K (2005) Feedback in the plant-soil system. Annual Review of Environment and Resources 30: 75-115.

Elakovich SD \& Wooten JW (1989) Allelopathic potential of sixteen aquatic and wetland plants. Toxicology 17: 129-182.

Enloe SF, DiTomaso JM, Orloff SB \& Drake DJ (2004) Soil water dynamics differ among rangeland plant communities dominated by yellow starthistle (Centaureasolstitialis), annual grasses, or perennial grasses. Weed Science 52(6): 929-935.

Fan L, Chen Y, Yuan JG \& Yang ZY (2010) The effect of Lantana camara Linn. invasion on soil chemical and microbiological properties and plant biomass accumulation in southern China. Geoderma 154(3-4): 370378.

Fang C \& Moncrieff JB (2001) The dependence of soil CO2 efflux on temperature. Soil Biology and Biochemistry 33(2): 155-165.

Flory SL \& Clay K (2010) Non-native grass invasion alters native plant composition in experimental communities. Biological Invasions 12(5): 1285-1294.

Freckleton RP \& Watkinson AR (2001) Asymmetric competition between plant species. Functional Ecology 15(5): 615-623.

Gaertner M, Den Breeyen A, Hui C \& Richardson DM (2009) Impacts of alien plant invasions on species richness in Mediterranean-type ecosystems: a meta-analysis. Progress in Physical Geography 33(3): 319338.

Gibbons SM, Lekberg Y, Mummey DL, Sangwan N, Ramsey PW \& Gilbert JA (2017) Invasive Plants Rapidly 
Reshape Soil Properties in a Grassland Ecosystem. mSystems 2: e00178-16.

Gioria M \& Osborne BA (2014) Resource competition in plant invasions: emerging patterns and research needs. Frontiers in Plant Science 5: 501.

Gioria M, Jarošík V \& Pyšek P (2014) Impact of invasions by alien plants on soil seed bank communities: emerging patterns. Perspectives in Plant Ecology, Evolution and Systematics 16(3): 132-142.

Gordon DR (1998) Effects of invasive, non-indigenous plant species on ecosystem processes: lessons from Florida. Ecological Applications 8(4): 975-989.

Gratton C \& Denno RF (2005) Restoration of arthropod assemblages in a Spartina salt marsh following removal of the invasive plant Phragmitesaustralis. Restoration Ecology 13(2): 358-372.

Gratton C \& Denno RF (2006) Arthropod food web restoration following removal of an invasive wetland plant. Ecological Applications 16(2): 622-631.

Grime JP (1998) Benefits of plant diversity to ecosystems: immediate, filter and founder effects. Journal of Ecology 86(6): 902-910.

Gurevitch J, Howard TG, Ashton IW, Leger EA, Howe KM, Woo E \& Lerdau M (2008) Effects of experimental manipulation of light and nutrients on establishment of seedlings of native and invasive woody species in Long Island, NY forests. Biological Invasions 10(6): 821-831.

Hamblin AP (1986) The influence of soil structure on water movement, crop root growth, and water uptake. In: Advances in Agronomy. Academic Press, pp. 95-158.

Hawkes CV, Wren IF, Herman DJ \& Firestone MK (2005) Plant invasion alters nitrogen cycling by modifying the soil nitrifying community. Ecology letters 8(9): 976-985.

Hector A, Schmid B, Beierkuhnlein C, Caldeira MC, Diemer M, Dimitrakopoulos PG, Fin JA, Freitas H, Giller S, Good J, Harris R, Hogberg P, Huss-Danell K, Joshi J, Jumponnen A, Korner C, Leadley PW, Loreau M, Minns A, Mulder CPH, O’Donovan G, Otway SG, Pereira JS, Prinz A, Read DJ, Scherer-Lorenzon M, Schulze ED, Siamantziouras ASD, Spehn EM, Terry AC, Troumbis AY, Woodward FI, Harris R, Hogberg P, Huss-Danell K, Joshi J, Jumpponen A, Korner C, Leadley PW, Loreau M, Minns A, Mulder CPH, O’Donovan G, Otway SJ, Pereira JS, Prinz A, Read DJ, Scherer-Lorenzen M, Schulze ED, Siamantziouras ASD, Spehn EM, Terry AC, Troumbis AY, Woodward FI, Yachi S \& Lawton JH (1999) Plant diversity and productivity experiments in European grasslands. Science 286(5442): 1123-1127.

Helsen K, Smith SW, Brunet J, Cousins SA, De Frenne P, Kimberley A, Kolb A, Lenoir J, Ma S, Michaelis J, Verheyen K, Speed JDM, Graae BI \& Plue J (2018) Impact of an invasive alien plant on litter decomposition along a latitudinal gradient. Ecosphere 9(1): e02097.

Herr C, Chapuis-Lardy L, Dassonville N, Vanderhoeven S \& Meerts P (2007) Seasonal effect of the exotic invasive plant Solidagogigantea on soil $\mathrm{pH}$ and $\mathrm{P}$ fractions. Journal of Plant Nutrition and Soil Science 170(6): 729-738.

Hiremath AJ \& Sundaram B (2005) The fire-lantana cycle hypothesis in Indian forests. Conservation and Society 3(1): 26.

Hobbie SE (2015) Plant species effects on nutrient cycling: revisiting litter feedbacks. Trends in Ecology and Evolution 30(6): 357-363.

Hobbs RJ \& Mooney HA (1986) Community changes following shrub invasion of grassland. Oecologia 70(4): 508-513.

Hughes RF \& Denslow JS (2005) Invasion by a N2-fixing tree alters function and structure in wet lowland forests of Hawaii. Ecological Applications 15(5): 1615-1628.

Hutchinson TF \& Vankat JL (1997) Invasibility and Effects of Amur Honeysuckle in Southwestern Ohio Forests: Invasibilidad y Efectos de la Madreselva de Amur en BosquesdelSudoeste de Ohio. Conservation Biology 11(5): 1117-1124.

Inderjit \& Cahill JF (2015) Linkages of plant-soil feedbacks and underlying invasion mechanisms. AoB plants 7: $1-8$.

Inderjit, Wardle D, Richard K \& Callaway RM (2011) The ecosystem and evolutionary contexts of allelopathy. Trends in Ecology and Evolution 26: 655-662.

Iponga DM, Milton SJ \& Richardson DM (2008) Superiority in competition for light: a crucial attribute defining the impact of the invasive alien tree Schinusmolle (Anacardiaceae) in South African savanna. Journal of Arid Environments 72(5): 612-623.

IUCN (2004). IUCN-the World Conservation Union Species Survival Commission. Invasive Species Specialist Group. Available from: http://www.issg.org/database/spp (accessed: 12 Nov. 2015). 
Jackson RB, Banner JL, Jobbágy EG, Pockman WT \& Wall DH (2002) Ecosystem carbon loss with woody plant invasion of grasslands. Nature 418(6898): 623.

Jiang JP, Xiong YC, Jiang HM, De-You YE, Ya-Jie SONG \&Feng-Min LI (2009) Soil microbial activity during secondary vegetation succession in semiarid abandoned lands of Loess Plateau. Pedosphere 19(6): 735-747.

Jones RO \& Chapman SK (2011) The roles of biotic resistance and nitrogen deposition in regulating non-native understory plant diversity. Plant and Soil 345(1-2): 257-269.

Jordan NR, Larson DL \& Huerd SC (2011) Evidence of qualitative differences between soil-occupancy effects of invasive vs. native grassland plant species. Invasive Plant Science and Management 4(1): 11-21.

Kandwal R, Jeganathan C, Tolpekin V \& Kushwaha SPS (2009) Discriminating the invasive species, 'Lantana' using vegetation indices. Journal of the Indian Society of Remote Sensing 37(2): 275.

Keddy PA \& Shipley B (1989) Competitive hierarchies in herbaceous plant communities. Oikos 54(2): 234241.

Kelly EF, Chadwick OA \& Hilinski TE (1998) The effect of plants on mineral weathering. Biogeochemistry 42(1-2): 21-53.

Kourtev PS, Ehrenfeld JG \& Häggblom M (2002) Exotic plant species alter the microbial community structure and function in the soil. Ecology 83(11): 3152-3166.

Kourtev PS, Ehrenfeld JG \& Häggblom M (2003) Experimental analysis of the effect of exotic and native plant species on the structure and function of soil microbial communities. Soil Biology and Biochemistry 35(7): 895-905.

Kourtev PS, Ehrenfeld JG \& Huang WZ (1998) Effects of exotic plant species on soil properties in hardwood forests of New Jersey. Water, Air, and Soil Pollution 105(1-2): 493-501.

Kueffer C, Schumacher EVA, Fleischmann K, Edwards PJ \& Dietz H (2007) Strong below-ground competition shapes tree regeneration in invasive Cinnamomum verum forests. Journal of Ecology 95(2): 273-282.

Kulmatiski A \& Kardol P (2008) Getting plant-soil feedbacks out of the greenhouse: experimental and conceptual approaches. In: Progress in botany. Springer, Berlin, Heidelberg, pp. 449-472.

Kulmatiski A (2006) Exotic plants establish persistent communities. Plant Ecology 187(2): 261-275.

Kulmatiski A, Beard KH, Stevens JR \& Cobbold SM (2008) Plant-soil feedbacks: a meta-analytical review. Ecology letters 11(9): 980-992.

Kumari P \& Choudhary AK (2016) Exotic species invasion threats to forests: A case study from theBetla national park, Palamu, Jharkhand, India. Tropical Plant Research 3(3): 592-599.

Lavelle P, Decaëns T, Aubert M, Barot S, Blouin M, Bureau F, Margerie P, Mora P \& Rossi JP (2006) Soil invertebrates and ecosystem services. European Journal of Soil Biology 42: S3-S15.

Levin LA, Neira C \& Grosholz ED (2006) Invasive cordgrass modifies wetland trophic function. Ecology 87(2): 419-432.

Levine JM, Vila M, Antonio CMD, Dukes JS, Grigulis K \& Lavorel S (2003) Mechanisms underlying the impacts of exotic plant invasions. Proceedings of the Royal Society of London Series B: Biological Sciences 270(1517): 775-781.

Liao C, Peng R, Luo Y, Zhou X, Wu X, Fang C, Chen J \& Li B (2008) Altered ecosystem carbon and nitrogen cycles by plant invasion: a meta-analysis. New Phytologist 177(3): 706-714.

Liao JD, Boutton TW \& Jastrow JD (2006) Storage and dynamics of carbon and nitrogen in soil physical fractions following woody plant invasion of grassland. Soil Biology and Biochemistry 38(11): 3184-3196.

Litt AR, Cord EE, Fulbright TE \& Schuster GL (2014) Effects of invasive plants on arthropods. Conservation Biology 28(6): 1532-1549.

Mack MC \& D'Antonio CM (2003) Exotic grasses alter controls over soil nitrogen dynamics in a Hawaiian woodland. Ecological Applications 13(1): 154-166.

Mack MC, D'Antonio CM \& Ley RE (2001) Alteration of ecosystem nitrogen dynamics by exotic plants: a case study of C4 grasses in Hawaii. Ecological Applications 11(5): 1323-1335.

Martin MR, Tipping PW \& Sickman JO (2009) Invasion by an exotic tree alters above and belowground ecosystem components. Biological Invasions 11(8): 1883-1894.

Mason TJ, French K \& Russell K (2012) Are competitive effects of native species on an invader mediated by water availability? Journal of Vegetation Science 23(4): 657-666.

McConnaughay KDM \& Bazzaz FA (1991) Is physical space a soil resource? Ecology 72(1): 94-103.

McCulley RL, Archer SR, Boutton TW, Hons FM \& Zuberer DA (2004) Soil respiration and nutrient cycling in wooded communities developing in grassland. Ecology 85(10): 2804-2817. 
McDougall KL, Alexander JM, Haider S, Pauchard A, Walsh NG \& Kueffer C (2011) Alien flora of mountains: global comparisons for the development of local preventive measures against plant invasions. Diversity and Distributions 17(1): 103-111.

McGrath DA \& Binkley MA (2009) Microstegium vimineum invasion changes soil chemistry and microarthropod communities in Cumberland Plateau forests. Southeastern Naturalist 8(1): 141-157.

Metcalfe DB, Fisher RA \& Wardle DA (2011) Plant communities as drivers of soil respiration: pathways, mechanisms, and significance for global change. Biogeosciences 8(8): 2047-2061.

Meyer III WM, Ostertag R \& Cowie RH (2011) Macro-invertebrates accelerate litter decomposition and nutrient release in a Hawaiian rainforest. Soil Biology and Biochemistry 43(1): 206-211.

Meyerson LA \& Mooney HA (2007) Invasive alien species in an era of globalization. Frontiers in Ecology and the Environment 5(4): 199-208.

Muñoz AA \& Cavieres LA (2008) The presence of a showy invasive plant disrupts pollinator service and reproductive output in native alpine species only at high densities. Journal of Ecology 96(3): 459-467.

Nannipieri P, Ascher J, Ceccherini M, Landi L, Pietramellara G \& Renella G (2003) Microbial diversity and soil functions. European Journal of Soil Science 54(4): 655-670.

Nernberg D \& Dale MR (1997) Competition of five native prairie grasses with Bromus inermis under three moisture regimes. Canadian Journal of Botany 75(12): 2140-2145.

Oades JM (1984) Soil organic matter and structural stability: mechanisms and implications for management. Plant and Soil 76(1-3): 319-337.

Olden JD \& Poff NL (2003) Towards a mechanistic understanding and prediction of biotic homogenization. The American Naturalist 162(4): 442-460.

Palladini JD \& Maron JL (2013) Indirect competition for pollinators is weak compared to direct resource competition: pollination and performance in the face of an invader. Oecologia 172(4): 1061-1069.

Pathak R, Negi VS, Rawal RS \& Bhatt ID (2019) Alien plant invasion in the Indian Himalayan Region: state of knowledge and research priorities. Biodiversity and Conservation 28: 3073-3102.

Pauchard A, Kueffer C, Dietz H, Daehler CC, Alexander J, Edwards PJ, Arevalo JR, Cavieres LA, Guisan A, Haider S, Jakobs G, McDougall L, Millar CI, Naylor BJ, Parks CG, Rew LJ \& Seipel T (2009) Ain't no mountain high enough: plant invasions reaching new elevations. Frontiers in Ecology and the Environment 7(9): 479-486.

Pearson DE (2009) Invasive plant architecture alters trophic interactions by changing predator abundance and behavior. Oecologia 159(3): 549-558.

Pineda A, Zheng SJ, van Loon JJ, Pieterse CM \& Dicke M (2010) Helping plants to deal with insects: the role of beneficial soil-borne microbes. Trends in Plant Science 15(9): 507-514.

Potts DL, Harpole WS, Goulden ML \& Suding KN (2008) The impact of invasion and subsequent removal of an exotic thistle, Cynara cardunculus, on $\mathrm{CO}_{2}$ and $\mathrm{H}_{2} \mathrm{O}$ vapor exchange in a coastal California grassland. Biological Invasions 10(7): 1073-1084.

Powell KI, Chase JM \& Knight TM (2011) A synthesis of plant invasion effects on biodiversity across spatial scales. American Journal of Botany 98(3): 539-548.

Powers JS, Montgomery RA, Adair EC, Brearley FQ, DeWalt SJ, Castanho CT, Chave G, Dienert E, Ganzhorn JU, Gilbert ME, González-Iturbe J A, Bunyavejchewin S, Grau HR, Harms KE, Hiremath A, Iriarte-Vivar S, Manzane E, D Oliveira AA, Poorter L, Ramanamanjato JB, Salk C, Varela A, Weiblen GD \& Lerdau MT (2009) Decomposition in tropical forests: a pan-tropical study of the effects of litter type, litter placement and mesofaunal exclusion across a precipitation gradient. Journal of Ecology 97(4): 801-811.

Pyšek P \& Richardson DM (2010) Invasive species, environmental change and management, and health. Annual Review of Environment and Resources 35: 25-55.

Pyšek P, Jarošík V, Hulme PE, Pergl J, Hejda M, Schaffner U \& Vilà M (2012) A global assessment of invasive plant impacts on resident species, communities and ecosystems: the interaction of impact measures, invading species' traits and environment. Global Change Biology 18(5): 1725-1737.

Qin Z, Xie JF, Quan GM, Zhang JE, Mao DJ \& Wang JX (2019) Changes in the soil meso-and micro-fauna community under the impacts of exotic Ambrosia artemisiifolia. Ecological Research 34(2): 265-276.

Radcliffe DE, Rasmussen TC \& Warrick AW (2002) Soil water movement. Soil Physics Companion. Boca Raton, London, New York, Washington DC, pp. 85-126.

Rai A, Singh AK, Ghosal N \& Singh N (2016) Understanding the effectiveness of litter from tropical dry forests for the restoration of degraded lands. Ecological Engineering 93:76-81. 
Rasher DB \& Hay ME (2014) Competition induces allelopathy but suppresses growth and anti-herbivore defence in a chemically rich seaweed. Proceedings of the Royal Society B: Biological Sciences 281(1777): 20132615. [DOI: 10.1098/rspb.2013.2615]

Rastogi J, Rawat DS \& Chandra S (2015) Diversity of invasive alien species in Pantnagar flora. Tropical Plant Research 2(3): 282-287.

Reinhart KO \& Callaway RM (2006) Soil biota and invasive plants. New Phytologist 170(3): 445-457.

Ricciardi A, Blackburn TM, Carlton JT, Dick JT, Hulme PE, Iacarella JC, Jeschke JM, Liebhold AM, Lockwood JL, Maclsaac HJ \& Pyšek P (2017) Invasion science: a horizon scan of emerging challenges and opportunities. Trends in Ecology and Evolution 32(6): 464-474.

Rice EL (1984) Allelopathy, $2^{\text {nd }}$ Edition. Academic Press, New York, pp. 422.

Rice EL (1992) Allelopathic effects on nitrogen cycling.In: Allelopathy. Springer, Dordrecht, pp. 31-58.

Rice EL (1974) Allelopathy. Academic Press, New York, pp. 353.

Richards CL, Bossdorf O, Muth NZ, Gurevitch J \& Pigliucci M (2006) Jack of all trades, master of some? On the role of phenotypic plasticity in plant invasions. Ecology Letters 9(8): 981-993.

Richardson DM \& Pyšek P (2012) Naturalization of introduced plants: ecological drivers of biogeographical patterns. New Phytologist 196(2): 383-396.

Richardson DM \& Rejmánek M (2011) Trees and shrubs as invasive alien species-a global review. Diversity and Distributions 17(5): 788-809.

Richardson DM, Pyšek P, Rejmánek M, Barbour MG, Panetta FD \& West CJ (2000) Naturalization and invasion of alien plants: concepts and definitions. Diversity and Distributions 6(2): 93-107.

Rickey MA \& Anderson RC (2004) Effects of nitrogen addition on the invasive grass Phragmites australis and a native competitor Spartina pectinata. Journal of Applied Ecology 41(5): 888-896.

Rothstein DE, Vitousek PM \& Simmons BL (2004) An exotic tree alters decomposition and nutrient cycling in a Hawaiian montane forest. Ecosystems 7(8): 805-814.

Saggar S, McIntosh PD, Hedley CB \& Knicker H (1999) Changes in soil microbial biomass, metabolic quotient, and organic matter turnover under Hieracium (H. pilosella L.). Biology and Fertility of Soils 30(3): 232-238.

Sala A, Smith SD \& Devitt DA (1996) Water use by Tamarix ramosissima and associated phreatophytes in a Mojave Desert floodplain. Ecological Applications 6(3): 888-898.

Sanon A, Beguiristain T, Cébron A, Berthelin J, Sylla SN \& Duponnois R (2012) Differences in nutrient availability and mycorrhizal infectivity in soils invaded by an exotic plant negatively influence the development of indigenous Acacia species. Journal of Environmental Management 95: S275-S279.

Sardans J \& Penuelas J (2005) Drought decreases soil enzyme activity in a Mediterranean Quercus ilex L. forest. Soil Biology and Biochemistry 37(3): 455-461.

Sardans J, Bartrons M, Margalef O, Gargallo-Garriga A, Janssens IA, Ciais P, Obersteiner M, Sigurdsson BD, Chen HYH \& Peñuelas J (2017) Plant invasion is associated with higher plant-soil nutrient concentrations in nutrient-poor environments. Global Change Biology 23(3): 1282-1291.

Sardans J, Peñuelas J \& Ogaya R (2008) Experimental drought reduced acid and alkaline phosphatase activity and increased organic extractable P in soil in a Quercus ilex Mediterranean forest. European Journal of Soil Biology 44(5-6): 509-520.

Sayer EJ (2006) Using experimental manipulation to assess the roles of leaf litter in the functioning of forest ecosystems. Biological Reviews 81(1): 1-31.

Schadler M \& Brandl R (2005) Do invertebrate decomposers affect the disappearance rate of litter mixtures? Soil Biology and Biochemistry 37(2): 329-337.

Schlesinger WH \& Andrews JA (2000) Soil respiration and the global carbon cycle. Biogeochemistry 48(1): 720.

Seabloom EW, Williams JW, Slayback D, Stoms DM, Viers JH \& Dobson AP (2006) Human impacts, plant invasion, and imperiled plant species in California. Ecological Applications 16(4): 1338-1350.

Sharma GP \& Raghubanshi AS (2011) Lantana camara L. invasion and impact on herb layer diversity and soil properties in a dry deciduous forest of India. Applied Ecology and Environmental Research 9(3): 253-264.

Si C, Liu X, Wang C, Wang L, Dai Z, Qi S \& Du D (2013) Different degrees of plant invasion significantly affect the richness of the soil fungal community. PLoS One 8(12): e85490.

Simba YR, Kamweya AM, Mwangi PN \& Ochora JM (2013) Impact of the invasive shrub, Lantana camara L. on soil properties in Nairobi National Park, Kenya. International Journal of Biodiversity and Conservation 5(12): 803-809. 
Singh BP \& Sainju UM (1998) Soil physical and morphological properties and root growth. HortScience 33(6): 966-971.

Smith DL \& Johnson L (2004) Vegetation-mediated changes in microclimate reduce soil respiration as woodlands expand into grasslands. Ecology 85(12): 3348-3361.

Smith MD, Wilcox JC, Kelly T \& Knapp AK (2004) Dominance not richness determines invasibility of tallgrass prairie. Oikos 106(2): 253-262.

Smith P L, Redente EF \& Hooper E (1987) Soil organic matter. In: Reclaiming Mine Soils and Overburden in the Western United States, Analytical Parameters and Procedures. Soil Conservation Society of America, Ankeny, pp. 185-214.

Soler R, Badenes-Pérez FR, Broekgaarden C, Zheng SJ, David A, Boland W \& Dicke M (2012) Plant-mediated facilitation between a leaf-feeding and a phloem-feeding insect in a brassicaceous plant: from insect performance to gene transcription. Functional Ecology 26(1): 156-166.

Standish RJ (2004) Impact of an invasive clonal herb on epigaeic invertebrates in forest remnants in New Zealand. Biological Conservation 116(1): 49-58.

Stefanowicz AM, Majewska ML, Stanek M, Nobis M \& Zubek S (2018) Differential influence of four invasive plant species on soil physicochemical properties in a pot experiment. Journal of Soils and Sediments 18(4): $1409-1423$.

Suding KN \& Goldberg DE (1999) Variation in the effects of vegetation and litter on recruitment across productivity gradients. Journal of Ecology 87(3): 436-449.

Sundarapandian SM \& Subashree K (2017) Status of invasive plants in Tamil Nadu, India: their impact and significance. In: Plant biodiversity: monitoring, assessment and conservation. pp. 371-387.

Sundarapandian SM, Muthumperumal C \& Subashree K (2015) Biological invasion of vines, their impacts and management.In: Biodiversity of Lianas. Springer, Cham, pp. 211-253.

Tallamy DW (2004) Do alien plants reduce insect biomass? Conservation Biology 18(6): 1689-1692.

Talley TS, Nguyen KC \& Nguyen A (2012) Testing the effects of an introduced palm on a riparian invertebrate community in Southern California. PloS one 7(8): e42460.

TeBeest M, Stevens N, Olff H \& Van Der Putten WH (2009) Plant-soil feedback induces shifts in biomass allocation in the invasive plant Chromolaena odorata. Journal of Ecology 97(6): 1281-1290.

Tharayil N, Alpert P, Bhowmik P \& Gerard P (2013) Phenolic inputs by invasive species could impart seasonal variations in nitrogen pools in the introduced soils: a case study with Polygonum cuspidatum. Soil Biology and Biochemistry 57: 858-867.

Thebaud C, Finzi AC, Affre L, Debussche M \& Escarre J (1996) Assessing why two introduced Conyza differ in their ability to invade Mediterranean old fields. Ecology 77(3): 791-804.

Theoharides KA \& Dukes JS (2007) Plant Invasion across Space and Time: Factors Affecting Nonindigenous Species Success during Four Stages of Invasion. New Phytologist 176: 256-273.

Thorpe AS, Thelen GC, Diaconu A \& Callaway RM (2009) Root exudate is allelopathic in invaded community but not in native community: field evidence for the novel weapons hypothesis. Journal of Ecology 97(4): 641-645.

Tiley GE, Dodd FS \& Wade PM (1996) Heracleum mantegazzianum Sommier \& Levier. Journal of Ecology 84(2): 297-319.

Tiwari S (2005) An inventory and assessment of invasive alien plant species of Nepal. IUCN Nepal.

Uddin MN \& Robinson RW (2017) Responses of plant species diversity and soil physical-chemical-microbial properties to Phragmites australis invasion along a density gradient. Scientific Reports 7(1): 11007.

Van Breemen N \& Finzi AC (1998) Plant-soil interactions: ecological aspects and evolutionary implications. Biogeochemistry 42(1-2): 1-19.

van der Heijden MG, Bardgett RD \& Van Straalen NM (2008) The unseen majority: soil microbes as drivers of plant diversity and productivity in terrestrial ecosystems. Ecology Letters 11(3): 296-310.

van der Putten WH, Bardgett RD, Bever JD, Bezemer TM, Casper BB, Fukami T, Kardol P, Klironomos JN, Kulmatiski A, Schweitzer JA, Suding KN, Van de Voorde TFJ \& Wardle DA (2013) Plant-soil feedbacks: the past, the present and future challenges. Journal of Ecology 101(2): 265-276.

Van Kleunen M, Dawson W, Essl F, Pergl J, Winter M, Weber E, Kreft H, Weigelt P, Kartesz J, Nishino M \& Antonova LA (2015) Global exchange and accumulation of non-native plants. Nature 525(7567): 100.

Van Kleunen M, Weber E \& Fischer M (2010) A meta-analysis of trait differences between invasive and noninvasive plant species. Ecology Letters 13(2): 235-245. 
Vanderhoeven S, Dassonville N, Chapuis-Lardy, Hayez M \& Meerts P (2006) Impact of the invasive alien plant Solidagogiganteaon primary productivity, plant nutrient content and soil mineral nutrient concentrations. Plant and Soil 286(1-2): 259-268.

Vila M \& Weiner J (2004) Are invasive plant species better competitors than native plant species? evidence from pair-wise experiments. Oikos 105(2): 229-238.

Vilà M, Espinar JL, Hejda M, Hulme PE, Jarošík V, Maron JL, Pergl J, Schaffner U, Sun Y \& Pyšek P (2011) Ecological impacts of invasive alien plants: a meta-analysis of their effects on species, communities and ecosystems. Ecology Letters 14(7): 702-708.

Vilà M, Weber E \& Antonio CM (2000) Conservation implications of invasion by plant hybridization. Biological Invasions 2(3): 207-217.

Vitousek PM (1994) Beyond global warming: ecology and global change. Ecology 75(7): 1861-1876.

Vivrette NJ \& Muller CH (1977) Mechanism of invasion and dominance of coastal grassland by Mesembryanthemum crystallinum. Ecological Monographs 47(3): 301-318.

Wang C, Han G, Jia Y, Feng X, Guo P \& Tian X (2011) Response of litter decomposition and related soil enzyme activities to different forms of nitrogen fertilization in a subtropical forest. Ecological Research 26(3): 505-513.

Wang C, Xiao H, Liu J, Wang L \& Du D (2015) Insights into ecological effects of invasive plants on soil nitrogen cycles. American Journal of Plant Sciences 6(01): 34.

Weiner J (1993) Competition among plants. Treballs de la Societat Catalana de Biologia 44: 99-109.

Wekhanya MNN (2016) The effect of invasive species lantana camara on soil chemistry at Ol-DonyoSabuk National Park, Kenya. Doctoral dissertation, Kenyatta University.

Wilsey BJ, Daneshgar PP \& Polley HW (2011) Biodiversity, phenology and temporal niche differences between native-and novel exotic-dominated grasslands. Perspectives in Plant Ecology, Evolution and Systematics 13(4): 265-276.

Winter M, Schweiger O, Klotz S, Nentwig W, Andriopoulos P, Arianoutsou M, Basnou C, Delpetrou P, Didziulis V, Hejda M, Hulme P E, Lambdon PW, Pergl J, Pysek P, Roy DB \& Ingolf Kuhn (2009) Plant extinctions and introductions lead to phylogenetic and taxonomic homogenization of the European flora. Proceedings of the National Academy of Sciences 106(51): 21721-21725.

Wolf JJ, Beatty SW \& Seastedt TR (2004) Soil characteristics of Rocky Mountain National Park grasslands invaded by Melilotus officinalis and M. alba. Journal of Biogeography 31(3): 415-424.

Wolkovich EM \& Cleland EE (2011) The phenology of plant invasions: a community ecology perspective. Frontiers in Ecology and the Environment 9(5): 287-294.

Wolkovich EM, Bolger DT \& Holway DA (2009) Complex responses to invasive grass litter by ground arthropods in a Mediterranean scrub ecosystem. Oecologia 161(4): 697-708.

Yadav V, Singh NB, Singh H, Singh A \& Hussain I (2016) Allelopathic invasion of alien plant species in India and their management strategies: A review. Tropical Plant Research 3(1): 87-101.

Zavaleta E (2000) The economic value of controlling an invasive shrub. AMBIO: a Journal of the Human Environment 29(8): 462-468.

Zhang L, Wang H, Zou J, Rogers WE \& Siemann E (2014) Non-native plant litter enhances soil carbon dioxide emissions in an invaded annual grassland. PLoS one 9(3): e92301. 